\title{
Reconsidering the Relationship between Biblical and Systematic Theology in the New Testament
}

\author{
Essays by Theologians and New Testament Scholars \\ Ed. by Benjamin E. Reynolds, Brian Lugioyo and Kevin J. Vanhoozer
}

[Die Beziehung zwischen biblischer und systematischer Theologie im Neuen Testament überdenken. Aufsätze von
systematischen Theologen und Neutestamentlern.]

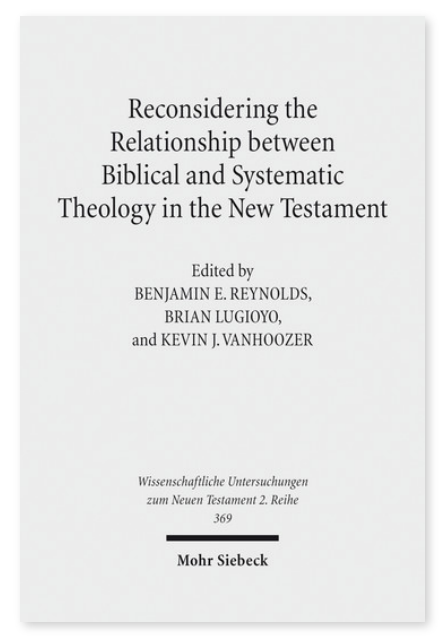

2014. XIV, 308 Seiten. WUNT II 369

ISBN 978-3-16-153029-6

DOI 10.1628/978-3-16-153029-6

eBook PDF $99,00 €$

ISBN 978-3-16-152719-7

fadengeheftete Broschur 99,00€
Veröffentlicht auf Englisch.

Die Beiträge dieses Bandes beschäftigen sich mit bestimmten Texten des Neuen Testaments und theologischen Lehren anhand der folgenden Fragen: Soll die systematische Theologie die biblische Theologie beherrschen oder umgekehrt? Sollten sie gleichgestellt werden? Wie würde das funktionieren? Ist die systematische Theologie notwendig oder hinderlich für die Exegese? Sollten systematisch-theologische Eigenheiten bei der exegetischen Untersuchung berücksichtigt werden? Diesen und andere Fragen gehen sowohl Neutestamentler als auch systematische Theologen nach, indem sie sich mit spezifischen biblischen Texte, theologischen Lehren oder historisch-theologischen Themen auseinandersetzen. Jeder der Beiträger wägt die Rolle der biblischen und der systematischen Theologie entweder in exegetischen Untersuchungen oder in der Formulierung theologischer Lehren ab. Der Band enthält ein Vorwort von Tremper Longman, III.

Inhaltsübersicht

Tremper Longman, III: Foreword - K evin J. Vanhoozer/Benjamin E. Reynolds/Brian Lugioyo: Introduction

Part One: Essays From the Perspective of Biblical Theology Mark Strauss: Christology or Christological Purpose in the Synoptic Gospels: A Study of Unity in Diversity - Benjamin E. Reynolds: The »Eucharistic « Language of John 6 in Biblical and Theological Perspective - Roy Kotansky: The Resurrection of Jesus in Biblical Theology: From Early Appearances (1 Corinthians 15) to the "Sindonology« of the Empty Tomb - Judith Gundry: Is Paul Worried about Anxiety or Care for People? The Theme of 1 Corinthians 7:32-34 and the Relation between Exegesis and Theology - J. Webb Mealy: Revelation is One: Revelation 20 and the Quest to Make the Scriptures Agree

Part Two: Essays From the Perspective of Systematic Theology Roger Newell: Instead of Sentimental Exegesis: The Significance of Suffering for Christ and his Church - Kevin J. Vanhoozer: The Origin of Paul's Soteriology: Election, Incarnation, and Union with Christ in Ephesians 1:4 (with special reference to Evangelical Calvinism) - Brian Lugioyo: Ministering to Bodies: Anthropological Views of Sōma in the New Testament, Theology, and Neuroscience - Jennifer Powell McNutt: James, »The Book of Straw, « in Reformation Biblical Exegesis: A Comparison of Luther and the Radicals - Gary Deddo: T.F. Torrance on Theological and Biblical Studies as Co-Servants of the Word of God, Living and Written - Stan D. Gaede: Postscript

Benjamin E. Reynolds Born 1977; 1999 BA Westmont College; 2003 MDiv; 2005 ThM Gordon-Conwell Theological Seminary; 2007 PhD University of Aberdeen; currently Associate Professor of New Testament, Tyndale University College, Toronto, ON, Canada.

Brian Lugioyo Born 1976; 1999 BA Westmont College; 2003 MAT Fuller Theological Seminary; 2007 PhD University of Aberdeen; currently Associate Professor of Theology and Ethics, Graduate School of Theology, Azusa Pacific University, Azusa, CA, USA.

Kevin J. Vanhoozer Born 1957; 1985 PhD; currently Research Professor of Systematic Theology at Trinity Evangelical Divinity School, Deerfield, IL, USA.

Jetzt bestellen:

https://mohrsiebeck.com/buch/reconsidering-the-relationship-between-biblical-and-systematic-theology-in-the-newtestament-9783161530296?no_cache=1

order@mohrsiebeck.com

Telefon: $+49(0) 7071-923-17$

Telefax: +49 (0)7071-51104 